\title{
Does the interaction between the knowledge management process and sustainable development practices boost corporate green innovation?
}

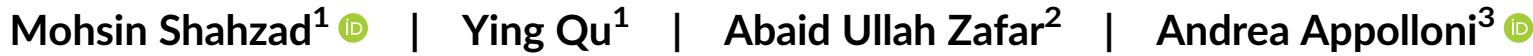

${ }^{1}$ School of Economics and Management, Dalian University of Technology, Dalian, China

${ }^{2}$ Shenzhen-Audencia Business School, Shenzhen University, Shenzhen, China

${ }^{3}$ Department of Management and Law, University of Rome Tor Vergata, Rome, Italy

Correspondence

Ying Qu, School of Economics and

Management, Dalian University of Technology,

Dalian, China.

Email: quying@dlut.edu.cn

\section{Present address}

Andrea Appolloni, School of Management, Cranfield University, Cranfield, Bedford, MK43 OAL, UK

Institute for Research on Innovation and Services for Development (IRISS), National Research Council 15 (CNR), 80134, Naples, Italy

\section{Funding information}

National Natural Science Foundation of China, Grant/Award Number: 71974028

\begin{abstract}
Green innovations are being deployed in manufacturing industries to promote organisational sustainability by embracing sustainable development practices (SDPs). However, little is known about how corporate green innovation (CGI) is influenced by the knowledge management process (KMP). To fill this gap, we have developed a multidimensional framework based on the resource-based view (RBV) theory that provides a foundation for sculpturing the process by which KMP was observed to capture and sustain CGI through SDPs. Data were collected from 393 respondents of large- and medium-sized manufacturing corporations in Pakistan and analysed using partial least squares structural equation modelling (SEM) and fuzzy set qualitative comparative analysis (fsQCA). This study provides several key findings. First, KMP dimensions (acquisition, dissemination and application) significantly improve the SDPs' dimensions (environment, economic and social). Second, SDP dimensions play a significant role in achieving CGI. Third, the implementation of SDPs partially mediates the relationship between the KMP and CGI. Furthermore, the fsQCA results signify the robustness of all integrated constructs. Our results demonstrate that investing in and adopting the latest technologies and sustainable practices are not only valuable for long-term success but the soft concerns such as managing organisational knowledge are also vital in the current knowledge-based economy. Finally, in light of our findings, theoretical and managerial implications, with propositions for future studies, have been provided at the end of the paper.
\end{abstract}

\section{KEYWORDS}

corporate green innovation, knowledge management process, structural equation modelling, sustainable development practices

\section{1 | INTRODUCTION}

The rapid consumption of natural resources and hazardous emissions resulting from economic progression has placed an amplified burden on the climate and the environment, rising with each passing day (Razzaq, Shrif, et al., 2021; United Nations, 2018). Many countries have failed to keep their environmental performance, per the report, of sustainable development goals (SDGs). Mounting scientific 
evidence of the harmful effects of this propensity has increased external pressure on organisations to respond to the challenges of environmental degradation (Awan et al., 2020). These pressures have heightened the focus on green and sustainable value creation and have fostered problems about whether sustainable development practices (SDPs) can address these issues while increasing competitiveness and sustainability (Wang, 2020; Yousaf, 2021).

Due to globalisation, businesses have recognised the value of the knowledge management process (KMP) as an effective tool to measure organisational competitiveness (Ooi, 2014). Organisations acquire, share and use knowledge for their benefit, which is the primary determinant of innovation (Darroch, 2005). The knowledge gained from various stakeholders allows management to formulate a strategic plan to create more revenue-generating opportunities and help them achieve green and sustainable objectives in different multinational organisations, such as Ikea, Unilever, Nike, Tesla, Honda, Matsushita, Canon, Anderson Consulting, British Petroleum and Boeing (Awan et al., 2020; Cui et al., 2020; Davenport et al., 2019). The KMP enables organisations to respond to dynamic changes and improve operational sustainability, which helps them to expand their green innovation agenda (Abbas \& Sağsan, 2019).

Corporate green innovation (CGI) has received much attention from researchers in the current decade due to rising environmental challenges and resource scarcity (Jun et al., 2019; Yousaf, 2021). It enables organisations to manufacture eco-friendly products and processes; thus, SDGs can be achieved (Abdul-Rashid et al., 2017; Awan et al., 2020; Razzaq, Wang, et al., 2021). However, due to a lack of implementation of green and sustainable practices reinforced by an effective KMP, manufacturing organisations continue to face significant challenges in achieving CGI. As Shahzad, Qu, Zafar, Ding, and Rehman (2020) identified, KMP is a critical factor that builds on the capabilities that offer the adoption of sustainable practices and influence CGI. Accordingly, the Global Innovation Index (GII) also highlighted the essential elements that hinder innovation: knowledge and creativity (GII, 2018). Pakistan is considered one of the least innovative nations in the world, with an abysmal ranking. Research on emerging economies such as Pakistan can provide better visions on how various strategies supported by KMP can control environmental deterioration and re-form eco-friendly products that protect ecological pollution and reduce industrial waste.

In the context of such developing nations, the absence of an adequate KMP in operational processes is a constraining factor for innovation, which is the primary concern of this study, as it disrupts SDPs implementation in the manufacturing industries (Shahzad, Qu, Zafar, Rehman, \& Islam, 2020). Further, the implementation of SDPs is an essential and driving factor for green innovation, which can be turned into higher environmental performance to remain in the global market by ensuring environmental stewardship (Song et al., 2020). In the current circular and knowledge-based economy, evidence shows that developed nations and larger organisations have switched from the classical means of production to innovative and customeroriented means by redesigning and regenerating natural systems, as they are more concerned about their health and environment
(Razzaqet, Wang, et al, 2021; Yousaf, 2021). Due to the Paris Agreement 2015, governments are also considerably more active in enacting stringent laws and regulations for manufacturing industries for combating environmental deterioration (Jun et al., 2019).

In this arena, where rivalry is increasing day by day, many researchers have explored the factors that affect $\mathrm{CGI}$ (refer to Appendix A). Some researchers have examined external factors that affect the organisational ability to foster green innovation, such as demands of the market, environmental regulations and greening of suppliers (Geng et al., 2021; Shah \& Soomro, 2021). Other researchers have examined internal factors that affect $\mathrm{CGI}$, such as corporate environmental ethics, innovation strategy and knowledge management strategy (Chang, 2016; Ding et al., 2019; Song et al., 2020). Awan et al. (2020) identified that acquisition and transfer of knowledge play a significant role in achieving green innovation. Further, Shahzad, Qu, Javed, Zafar, and Rehman (2020) found that environmental sustainability positively influences green innovation adoption. Green capabilities and green practices also strongly influence green innovation (Yousaf, 2021). Moreover, Saunila et al. (2018) also identified that environmental, social and economic sustainability considerably affect green innovation investment and exploitation. However, green and SDPs are still in their infancy in developing countries (Abdul-Rashid et al., 2017; Gupta \& Barua, 2018; Khan et al., 2021). There is a dire need for a comprehensive study that focuses on implementing SDPs for CGI in emerging nations. However, although several empirical studies have attempted to address these issues using developed and developing countries' samples, Pakistan is distinct for the following reasons. Since the China-Pakistan Economic Corridor (CPEC) was launched in 2013 as a blueprint for the Belt and Road Initiative, organisations from partnering countries have been more actively exchanging knowledge, technologies, and expertise and developing strategic relationships (An et al., 2021). Local organisations also realise the importance of SDPs and the latest technology spillovers to meet the stringent requirements for international trade and investment. Hence, the current study primarily examines the effects of the KMP on SDPs to enhance the CGI of Pakistan. To the best of our knowledge, researchers have paid scant attention to this complex phenomenon, and no work is available that examines the impact of the KMP on SDPs. Furthermore, providing empirical evidence regarding the effects of SDPs on CGI is another target of this research. This study envisions reducing the uncertain situation in respect of these relationships by incorporating the following research questions:

- What is the effect of the KMP on SDPs and further on CGI?

- Do SDPs mediate the relationship between the KMP and CGI?

The experiential examination of these research questions makes various contributions to the literature. First, the proposed theoretical model aims to analyse the extent to which the KMP will determine the SDP and $\mathrm{CGI}$ of organisations from a knowledge-intensive perspective, using multivariate analysis by structural equation modelling (SEM) and fuzzy set qualitative comparative analysis (fsQCA). Second, this study throws light on a fundamental concept of 
firms' SDPs that enhances CGI, which is still underexplored. Third, this study centres around SDPs in developing country contexts, such as Pakistan, which has less coverage in prior literature. This study also enables professionals and managers to assimilate KMP strategies into firm processes to improve sustainability and innovation. This research demonstrates the relevance of KMP in day-to-day manoeuvres and sheds light on how organisations can improve CGI. The next section consists of the theoretical background and literature review. Section 3 is related to hypotheses development. Section 4 explains the research methods, Section 5 provides the results and discussion and Section 6 provides the conclusion and policy implications.

\section{2 | THEORETICAL FRAMEWORK AND LITERATURE REVIEW}

\section{$2.1 \quad$ RBV theory}

In the last decade, many research studies have focused on the internal industrial determinants of organisational success. The resource-based view (RBV) was widely used in strategic management to describe internal organisational strengths and weaknesses and their relationship to competitiveness and success (Barney et al., 2011). The RBV is a complementary theory; it can help understand how an organisation can use the best resources and tools to enhance specific production/ logistic efficiency (Savino \& Shafiq, 2018). This theory suggests that organisations gain a competitive advantage by clustering different productive resources (tangible and intangible). These productive resources refer to all skills, tools, administrative processes, knowledge and expertise, organisational attributes, information and facts and so on, enabling the organisation to 'conceive of and implement strategies that improve its efficiency and effectiveness' (Barney, 1991). Further, Barney (1991) characterised these physiognomic resources as being VRIN: (a) valuable, (b) rare, (c) inimitable and (d) nonsubstitutable. The $\mathrm{RBV}$, on the other hand, is constrained to describing firm-level consequences and disregards the impact of SDPs on environmental and green performance (Andersén, 2021). By responding to this, Hart (1995) established a natural RBV (NRBV). The NRBV extends the boundaries of RBV and recognises the importance of the environment and can be seen as 'a theory of competitive advantage based upon the firm's relationship to the natural environment' (Hart, 1995).

The NRBV seeks to investigate how organisational resources can lead to strategic benefits and favourable environmental results. Ecologists and environmentalists have proposed that CGI can make an enterprise more prosperous and increase its long-term success by adopting an NRBV perspective (Shahzad, Qu, Zafar, Ding, \& Rehman, 2020). It does, however, depend on appropriate and vital organisational resources and capabilities (Sarkis et al., 2010). The ability to consistently improve and optimise manufacturing processes, for example, will result in lower emissions and costs (Hart, 1995), and a 'capability of strategic proactivity' will enjoy first-mover benefits and more aggressive environmental protection (Andersén, 2021). Similarly, knowledge resources, as a driving force for economic growth, have spawned a knowledge-based view of the corporation (Grant, 1997; Mills \& Smith, 2011). It asserts that competitiveness is determined by its ability to integrate specific knowledge resources, which can be used to develop core competencies for improving sustainable and green performance (Abbas \& Sağsan, 2019).

In the current circular and knowledge-based economy, relying on SDPs and the KMP is the right option for CGI, since it can improve corporate and national growth by employing the principles of redesigning and regeneration of natural systems (Awan et al., 2020). An RBV supports the framework in which an organisation with a higher KMP and employing SDPs has a better chance of producing green and sustainable products. Furthermore, current research claims that through the SDP, the KMP helps make an innovative and green product with less impact on the environment and society, increasing CGI.

\section{2 | Knowledge management process}

Different organisations exercise 'knowledge' as power over others to better understand and develop competitive strategies (Nonaka, 1994). Knowledge is created through communications between people and social structures; it is defined as 'a set of defensible beliefs that could facilitate an individual action' (Nonaka, 1994). Ooi (2014) stated that 'Knowledge is an intangible asset' and is a provenance of competitive edge for individuals and organisations because it is hard to emulate. Previous studies suggested that knowledge gained from different stakeholders, such as suppliers, consumers and research institutions, is vital for organisations to generate green innovation (Cui et al., 2020; Tseng et al., 2018). It can also be stated that the KMP assists businesses in deliberate decision making by gathering data and information from both internal and external sources (Ooi, 2014). Previous research studies have employed various aspects of the KMP (Abbas \& Sağsan, 2019; Darroch, 2005; Ooi, 2014; Shahzad, Qu, Zafar, Ding, \& Rehman, 2020). Following these studies, we employed these three dimensions of the KMP: knowledge acquisition (KACQ), knowledge dissemination (KDISS) and knowledge application (KAPP).

$\mathrm{KACQ}$ is a core component of the KMP; in this, firms attain new and advanced knowledge from diverse stakeholders to ensure constant enhancement in every organisation (Shahzad et al., 2019). In light of the dynamic developments in today's business environment, KACQ provides an improved understanding of every matter, such as financial, customer's preferences and organisational development, for continuous improvement in product and service quality (Darroch, 2005). Second, to ensure excellence, it is fundamental that employees are actively involved in the assimilation of knowledge (Song et al., 2020). Employees' participation in sharing valuable knowledge among various departments of the organisation is essential to achieve their desired objectives (Awan et al., 2020). Finally, firms should apply the knowledge acquired from clients/customers and other stakeholders and share it among employees to enhance the overall firm's operations right up to the finished product (Cui et al., 2020). Knowledge-driven enterprises promote staff involvement in corporate affairs and offer feasible solutions vigorously. This might 
not occur without carefully managing the acquisition, distribution and application of relevant knowledge among the various departments.

\subsection{SDPs and CGI}

In the early 1990s, sustainable development (SD) as a contemporary tactic was initiated as a development solution that bonds with the economic, social and environmental aspects of complex problems in various sectoral and regional levels with different policy initiatives (Tseng et al., 2018). These foundations of SD are acknowledged as a triple bottom line (TBL) 'that affects the present and future generations' (Elkington, 1998). The TBL approach focuses on adopting green and eco-friendly strategies and technologies to develop eco-friendly products to alleviate environmental pollution and climate change risks (Tseng et al., 2018). Several perspectives encourage an organisation to pursue SDPs, such as ethical, legal and commercial. In this study, these three SDP dimensions have been selected: sustainable environment practices (ENV), sustainable economic practices (ECO) and sustainable social practices (SOC).

To avoid environmental destruction, global warming and continued climate change, we need to take an active part in controlling industrial decomposition for ecological sustainability. From the economic perspective of SDPs, organisations that have given careful consideration to improving eco-sustainability by reducing unfortunate results from production processes will also reinforce their financial and economic sustainability (Saunila et al., 2018). Social aspects are mainly associated with ensuring and improving external and internal communities' safety and health, promoting communication among them and providing equal opportunities and well-being (Saunila et al., 2018). With increasing demands for SD, organisational competing criteria have been expanded to include interdisciplinary economic, social and environmentally sustainable practices (Wang, 2020). The assessment of these SDPs is viewed as identifying indispensable drivers of $\mathrm{CGI}$.

CGI is a concept that is both internally driven and externally responsive; it not only has the characteristics of novelty and value of innovation but also emphasises the attributes of conservation of resources and environmental development (Ardito et al., 2019). Scholars are currently stressing the competitive advantage obtained through a firm's green and sustainable practices and their effect on CGI (Awan et al., 2020). Green innovation strives to reduce pollution by developing new products, services, processes and procedures, reducing organisational adverse environmental effects (Abbas, 2020). Further, Chen et al. (2006) stated its position as 'the main driver of socio-economic growth in the long term'. For this research, CGI indicates the extent to which organisations have improved their green processes and product innovation in the last 3 years.

Accordingly, Abbas and Sağsan (2019) endorsed that CGI can refer to both green products and green process innovation. Such developments aim to diminish natural resource utilisation, capitalise on renewable resources and reduce wastage. In particular, the manufacturing organisations transform the classical way of the product lifecycle from acquiring resources into the development of the product, supply chain, consumption and reprocessing CGI (Awan et al., 2020). Ardito et al. (2019) considered organisations that adopted green practices to have huge potential to attract more consumers. An SDP is one of the leading tactics for improving innovation that meets customers' needs and wants, and this is the most important factor for corporations to make green and sustainable products.

\section{3 | HYPOTHESES DEVELOPMENT}

\subsection{KMP and SDPs}

\subsubsection{Knowledge acquisition}

KACQ refers to discovering and acquiring new knowledge essential for effective firms' operations from various sources, boosting individual and organisational performance (Darroch, 2005). The primary purpose of KACQ is to identify consumers' needs and their responses regarding products and services. Integration of a green and sustainable agenda improves the probability of collaboration and communication with external stakeholders and grasps their latest technologies and knowledge (Shah \& Soomro, 2021). Past researchers have found a positive relationship between KACQ and performance innovativeness (Cui et al., 2020; Darroch, 2005). Although some researchers have exposed a negative relationship between KACQ and organisational performance, they still recommend investment in R\&D for new ideas generation for innovation performance (Mills \& Smith, 2011). Lee et al. (2013) identified that KACQ positively affects enterprise performance.

Recently, Abbas and Sağsan (2019) specified that organisations should apply attained knowledge in their processes to accomplish SD goals. Shahzad et al. (2019) acknowledged that knowledge absorption strongly affects sustainable organisational practices. These studies highlighted the significant role of knowledge and how KACQ helps attain SDPs (environmental, economic and social). Hence, the below hypotheses are proposed:

H1a. KACQ has a positive impact on sustainable environment practices.

H1b. KACQ has a positive impact on sustainable economic practices.

H1c. KACQ has a positive impact on sustainable social practices.

\subsection{2 | Knowledge dissemination}

KDISS gathers, shares and transmits knowledge among staff members to improve the firm's processes (Shahzad, Qu, Zafar, Rehman, \& Islam, 2020). It may have multiple dimensions, such as sharing and 
collection of knowledge; sharing means to propose knowledge, while collection relates to a compiling of knowledge among staff members and employees (Lee et al., 2013). Mills and Smith (2011) found that knowledge sharing is positively related to service performance. The past research has suggested that it could be a prevalent mode of social interaction and cooperation within an organisation that empowers employees to solve problems by providing support and innovative solutions (Awan et al., 2020).

For achieving higher performance outcomes, organisations should advance the knowledge-sharing behaviour of employees (Song et al., 2020). Abbas and Sağsan (2019) stated that sharing knowledge influences organisational sustainability positively through green technology and management innovation. Further, Shahzad, Qu, Zafar, Rehman, and Islam (2020) identified that KDISS positively influences sustainable corporate performance. The stream of knowledge around the organisation increases the knowledge-sharing rate among the subdivisions and diverse hierarchical levels; it will further increase the likelihood of sustainable improvement (environmental, economic and social). Thus, the below hypotheses are proposed:

H2a. KDISS has a positive impact on sustainable environment practices.

H2b. KDISS has a positive impact on sustainable economic practices.

H2c. KDISS has a positive impact on sustainable social practices.

\subsection{3 | Knowledge application}

KAPP is the assimilation of already attained knowledge in designing and delivering finished products to enhance overall operations and performance (Mills \& Smith, 2011). It is also recognised as a response to knowledge (Lee et al., 2013). An example of KAPP is when an organisation collects information about its clients' demands and market trends and reacts swiftly to that information to improve organisational processes. It is a fundamental component for generating core competencies in organisations for enhancing their performance. Darroch (2005) found that KAPP is an indispensable element for effective technological and performance advancement. It is a strategic resource for organisations to sustain performance in the modern era of competitiveness.

KAPP also permits organisational ability and knowledge to be transformed into the process and product development (Mills \& Smith, 2011). The practical application of knowledge allows organisations to manufacture sustainable products through advanced, innovative and digital manufacturing technologies (Awan et al., 2020). Current scholars have specified that KAPP has been used to support a firm's sustainable practices to achieve green growth outcomes (Abbas \& Sağsan, 2019; Shahzad, Qu, Zafar, Ding, \& Rehman, 2020). Accordingly, the practical application of knowledge can be processed from being a potential ability into a realised and energetic ability that influences corporate performance (Mills \& Smith, 2011). Therefore, we propose that KAPP ties in with SDPs (environmental, economic and social). Thus, the below hypotheses are proposed:

H3a. KAPP has a positive impact on sustainable environment practices.

H3b. KAPP has a positive impact on sustainable economic practices.

H3c. KAPP has a positive impact on sustainable social practices.

\subsection{SDPs and CGI}

\subsection{1 | Sustainable environment practices (ENV)}

Sustainable environmental practices help transform product manufacturing technologies in order to diminish negative influences on the environment and minimise industrial waste (Saunila et al., 2018). Organisations need to consider utilising innovative and environmentally friendly technologies that point towards effective resource utilisation to reduce consumption and deterioration (Song et al., 2020). Prior studies have acknowledged that organisations that have already adopted environmental strategies and sustainable policies into their processes would be able to deliver green products (Huang \& Li, 2017).

Shah and Soomro (2021) found that proactive environmental strategies increase internal green integration for environmental performance. Recent research has also suggested that environmental readiness enhances corporate innovation and competitive advantage (Zhang et al., 2020). Extant literature has identified that environmental sustainability is the core element for green innovation exploitation and investment (Saunila et al., 2018). Those organisations that are more environmentally conscious compel green performance (Chang, 2016). Eco-efficient enterprises can swiftly fulfil the requirements needed to avoid environmental deterioration (Ardito et al., 2019).

Moreover, Shahzad, Qu, Javed, Zafar, and Rehman (2020) revealed that environmental sustainability positively affects green innovation. Consequently, environmental motivation and awareness of environmental activities are imperative for green innovation in the current business era. Thus, the below hypothesis is proposed:

H4a. Sustainable environment practices have a positive impact on CGI.

\subsection{2 | Sustainable economic practices (ECO)}

ECO comprise two diverse views; one is associated with financial performance, and the other is related to community well-being (Saunila 
et al., 2018). It has been most widely studied after the global economic depression identified the risks of bankruptcy and insolvency (Geng et al., 2021). Prior studies acknowledged that cost-saving and recycling are the most imperative motivators for the lowest utilisation of energy and raw material (Ardito et al., 2019). Tseng et al. (2018) stressed that employing recycling principles in organisational logistics contributes to waste reduction and energy saving, strengthening a sustainable economy. A previous study identified that reducing production costs positively affects green innovation (Abdul-Rashid et al., 2017).

Abbas (2020) showed that corporate social responsibility (CSR) also significantly affects corporate green performance regarding community well-being. Shahzad, Qu, Zafar, Ding, and Rehman (2020) identified that concerned stakeholders, such as communities and NGOs, affect green innovation. Another study found that firm profitability is positively significant for green product innovation, although green process innovation is insignificant (Li et al., 2017). Nevertheless, the association is not established concerning CGI. These uncertain circumstances have prompted scholars to examine the association; therefore, the below hypothesis is further proposed:

H4b. Sustainable economic practices have a positive impact on CGI.

\subsection{3 | Sustainable social practices (SOC)}

SOC are identified as organisational efficiency regarding the environment, focusing on human capital growth, job creation and society's well-being (Saunila et al., 2018). The internal knowledge capabilities and development initiatives have significantly enhanced green innovation (Lim et al., 2017). Environmental training and human capital development could also impel staff members to change their attitude and behaviour towards eco-friendly actions (Awan et al., 2020). In our context, the influence of green innovation can be realised through variation in behaviour and attitude, especially by driving towards technology adoption for cooperation and consumption (Hojnik \& Ruzzier, 2016). Extant literature has revealed that environmental knowledge affects social support and organisational profitability (Nidumolu et al., 2013). Nevertheless, both human capital development and internal learning stimulate the process of green innovation. Now, consumers are happy and keen to pay more for green and eco-friendly products to increase ecological performance and ultimately enhance profitability (Song \& Yu, 2018). Prior literature recognised that the social dimension of sustainability positively influences green innovation exploitation and investment (Saunila et al., 2018). It is determined that organisational requirements, green consumer demand, human capital and internal knowledge capabilities influence green innovation. Therefore, the below hypothesis is proposed:

H4c. Sustainable social practices have a positive impact on CGI.

\section{3 $\quad$ The mediating role of SDPs}

The significance of SDPs has remained a key consideration among scholars from diverse fields. For instance, Nidumolu et al. (2013) highlighted that SDP is a fundamental element for improving green innovation. Besides, KMP is an essential tactic and enabler for organisations to enhance innovation performance (Darroch, 2005). To achieve better outcomes, it must capitalise through an adequate organisational strategy and top management commitment. The KMP, SDPs and CGI association arises once top management shows commitment to preventing environmental deterioration and spends quality time adopting environmentally friendly and green resources to improve green innovation by managing the knowledge and capabilities of employees (Abbas \& Sağsan, 2019; Ooi, 2014). In this context, organisational learning emphasises integrating knowledge resources and sustainable corporate practices to accomplish long-term objectives (Davenport et al., 2019). Extant literature has acknowledged and presented a positive link between the KMP and green innovation (Abbas \& Sağsan, 2019; Lee et al., 2013; Shahzad, Qu, Zafar, Rehman, \& Islam, 2020; Song et al., 2020). Darroch (2005) indicated that distinctive kinds of innovation require various sources and, subsequently, a different KMP strategy. Previous researchers have also studied the direct association between multiple dimensions of sustainability and green innovation (Chang, 2016; Saunila et al., 2018). However, no study is available on the mediating role of SDPs between the KMP and CGI in the extant literature. So this research pursues determining whether SDPs act as an intermediary between the KMP and CGI. Following the aforesaid researchers, it can be argued that SDPs will mediate the association of KMP and CGI in the following hypothesised way.

H5. SDPs mediate the relationship between the KMP and CGI.

In Figure 1, the research model keeps in mind the research hypotheses to be tested in this study.

\section{4 | RESEARCH METHODS}

\subsection{Sample and procedure}

Based on the deductive approach, the current research focuses on testing the hypotheses derivative from the theory. A cross-sectional survey method was employed to accumulate data through an offline and online self-administered questionnaire for testing the hypotheses. This study's population consisted of manufacturing organisations, including construction and chemicals, surgical and dental supplies, paper and printing, pharmaceuticals, textile and leather products, wood and furniture and manufacturing and processing. They had all obtained ISO 9001 and ISO 14001 certification and were listed in the Pakistan stock exchange. Manufacturing organisations were chosen as this sector primarily harms both the environment and natural 


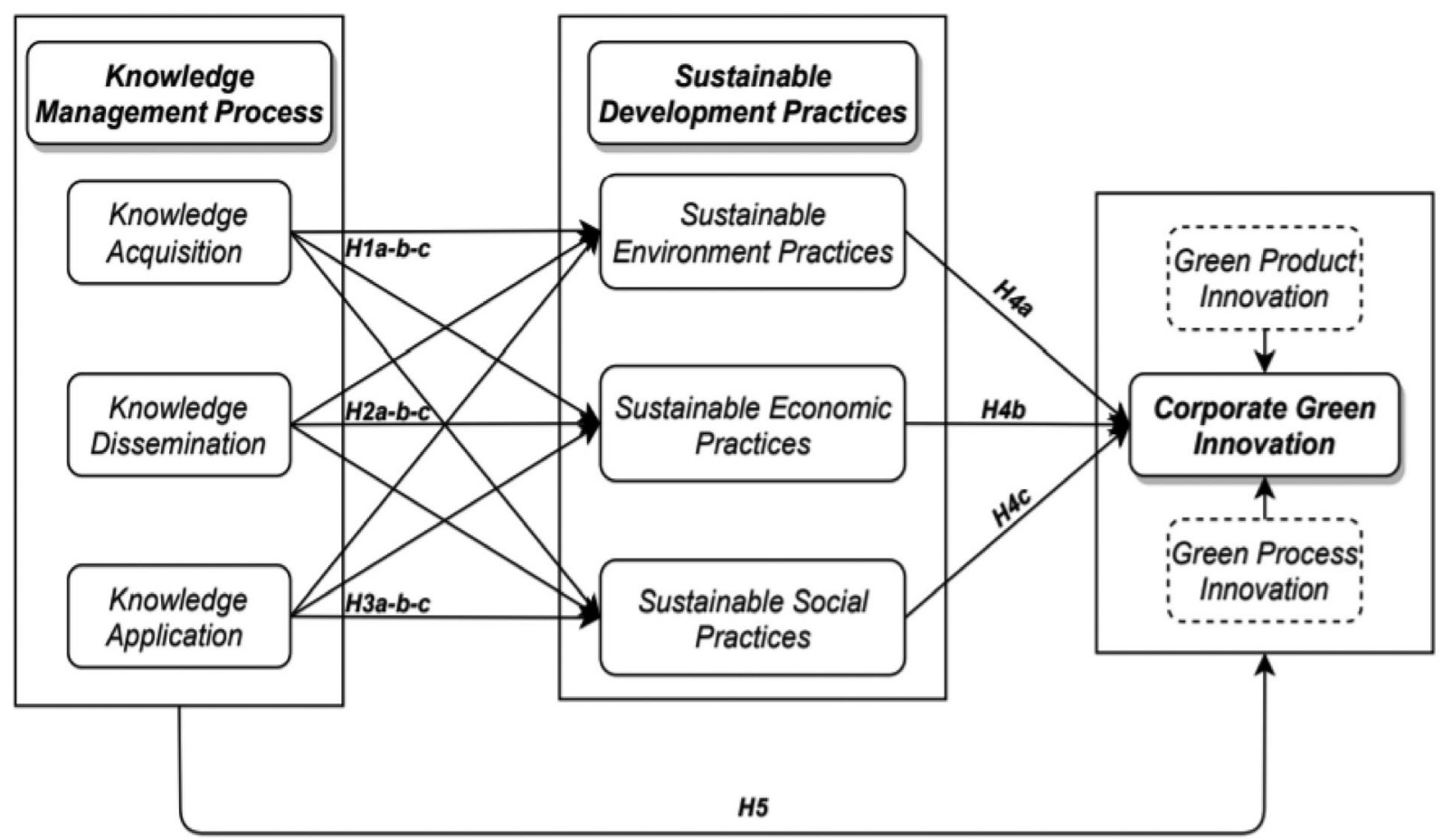

FIGURE 1 Research model

resources (Shahzad, Qu, Zafar, Rehman, \& Islam, 2020). Pakistan also faces the pressing challenges of sustainability and requires significant green innovation development. On the other hand, Pakistan is also important for this research as it is a critical player in the CPEC and is increasingly considered to be a major emerging economy (Awan et al., 2020). These listed corporations publish their annual and sustainability reports on their website and also in print media. Appropriate respondents for such an investigation are the company's middle and top management since they hold a critical position and have relevant information. Concurrently, they play a positive role in disseminating knowledge among different divisions (Ooi, 2014). The respondents were given the link to the online survey attached to a cover letter explaining the principal objective and guaranteed data confidentiality. More than 1100 respondents (CEO/managing director, senior manager, supervisors and executives) were approached through various means, both online and offline, from June to September 2019, with 435 responses received. Because some respondents did not fill out the desired information, 42 responses were discarded due to judgement errors, and 393 functional responses were included. Almost $59 \%$ of the respondents were supervisors and senior managers. A master's degree was held by the majority of respondents (40\%). Complete demographic details are given in Table 1.

All measures were concluded based on the recommendations of a panel of three professors and industry specialists to ensure face validity. A pilot study was conducted with a sample of 52 respondents before starting a formal data collection to guarantee content validity and reliability. A few modifications were integrated to ensure the questionnaire's reliability and validity, and the overall results established the formal data collection. For sample size, this research adopted the 10 times rule, suggested by Hair et al. (2017): '10 times the largest number of structural paths directed at a particular latent construct in a structural model'. The minimum sample size was also calculated using power analyses by G*Power software (Prajapati et al., 2010). The series of power analyses depicted that the final valid sample was good enough to proceed further.

\section{2 | Measures}

The study employed a 7-point Likert scale to measure latent constructs (1 represented strongly disagree and 7 strongly agree). The authors drew all the measured items and scale from the prior literature and modified them within the study context. All the constructs for this research were adapted from published literature with a few minor adjustments to guarantee contextual consistency after checking by three experts.

\subsection{1 | Knowledge management process}

The KMP construct was measured by Darroch (2005) with three key dimensions: acquisition, dissemination and application of knowledge. KACQ was measured using a six-item scale to capture and realise the knowledge and its attainment. Further, KDISS was measured using a five-item scale representing knowledge assimilation and its transfer internally and externally. Furthermore, KAPP was measured using a five-item scale representing swift adoption and response of 


\begin{tabular}{|c|c|c|c|}
\hline \multicolumn{2}{|c|}{ Respondent profile } & \multicolumn{2}{|l|}{$(n=393)$} \\
\hline Attributes & Distribution & Frequency & $\%$ \\
\hline \multirow[t]{3}{*}{ Gender } & Male & 219 & 55.73 \\
\hline & Female & 161 & 40.97 \\
\hline & Prefer not to say & 13 & 3.31 \\
\hline \multirow[t]{4}{*}{ Age } & $20-29$ years & 129 & 32.82 \\
\hline & $30-39$ years & 180 & 45.80 \\
\hline & $40-49$ years & 64 & 16.28 \\
\hline & More than 50 years & 20 & 5.09 \\
\hline \multirow[t]{4}{*}{ Education } & Bachelor's degree & 137 & 34.86 \\
\hline & Master's degree & 158 & 40.20 \\
\hline & Technical degree & 56 & 14.25 \\
\hline & Others & 42 & 10.69 \\
\hline \multirow[t]{4}{*}{ Job experience } & $0-5$ years & 99 & 25.19 \\
\hline & $6-10$ years & 164 & 41.73 \\
\hline & $11-15$ years & 81 & 20.61 \\
\hline & More than 15 years & 49 & 12.47 \\
\hline \multirow[t]{4}{*}{ Job title } & Officer/coordinator & 142 & 36.13 \\
\hline & Supervisor/manager & 171 & 43.51 \\
\hline & Senior manager/general manager & 60 & 15.27 \\
\hline & Managing director/CEO & 20 & 5.09 \\
\hline
\end{tabular}

TABLE 1 Details of demographic attributes knowledge. We used the KMP's scale, which has been used frequently in prior literature (Abbas \& Sağsan, 2019; Lee et al., 2013; Shahzad, Qu, Zafar, Rehman, \& Islam, 2020).

\subsection{2 | Sustainable development practices}

The three-dimensional construct of SDPs was measured following studies by Saunila et al. (2018), including environmental, economic and social sustainable practices. Each dimension was measured using four to five items representing organisational practices related to reducing and handling toxic waste, decreasing the probability of hazards, reducing energy consumption, cost efficiency and revenue generation, health and safety and community well-being. This scale has been used often in prior research (Saunila et al., 2018).

\subsection{3 | Corporate green innovation}

To evaluate CGI, a six-item construct was adapted from Chang (2016) and Song and $Y u$ (2018), indicating the extent to which organisations had improved their green processes and product innovation during the last 3 years. CGI can improve products or processes regarding pollution alleviation, recycling and green product design for ecofriendly production and enhancing performance. We used the CGI construct, as it has also been frequently used in prior studies (Awan et al., 2020; Shahzad, Qu, Zafar, Ding, \& Rehman, 2020; Song \& Yu, 2018).

\section{5 | DATA ANALYSIS}

The current research employs the partial least squares SEM (PLS-SEM) and fsQCA by using different software, that is, SmartPLS version 3.2.7 and fsQCA version 3.0. PLS-SEM is suitable for complex model analyses. The focus of this research is predicting the endogenous variable to explain the maximum variance. Also, PLS-SEM can handle both the outer (measurement) and inner (structural) models concurrently (Hair et al., 2017). The SEM approach has shortcomings, such as causal symmetry and net effects. Multiple regression analysis (MRA) and SEM have inherent problems due to these limitations (Woodside, 2017). Following Ragin et al. (2017), we employed fsQCA to overcome these shortcomings, as it is a valuable tool to address uncertainty. Mainly, PLS-SEM is employed to test the proposed model, and then, the fsQCA is used to test the robustness. Following Hair et al. (2017), estimation of the structural and measurement model was performed specifically to ensure valid results.

\subsection{Common method variance and nonresponse bias test}

Common method bias (CMB) is a potential problem that can affect the content of the format and the response of the items, causing measurement error (Podsakoff et al., 2003). We checked the common method variance problem using Harman's single-factor test and employed exploratory and unrotated factor analysis techniques (Harman, 1976). The results indicated that no single factor 
TAB LE 2 Reliability and validity of all constructs

\begin{tabular}{|c|c|c|c|c|}
\hline Latent constructs & Factor loadings & Composite reliability & Cronbach's alpha & AVE \\
\hline \multicolumn{5}{|l|}{ Knowledge management process (KMP) } \\
\hline Knowledge acquisition & & 0.930 & 0.910 & 0.690 \\
\hline KACQ2 & 0.805 & & & \\
\hline KACQ3 & 0.854 & & & \\
\hline KACQ5 & 0.845 & & & \\
\hline KACQ6 & 0.817 & & & \\
\hline Knowledge dissemination & & 0.925 & 0.899 & 0.712 \\
\hline KDISS1 & 0.831 & & & \\
\hline KDISS2 & 0.836 & & & \\
\hline Knowledge application & & 0.905 & 0.869 & 0.656 \\
\hline KAPP1 & 0.866 & & & \\
\hline KAPP2 & 0.867 & & & \\
\hline KAPP3 & 0.815 & & & \\
\hline KAPP4 & 0.838 & & & \\
\hline KAPP5 & 0.832 & & & \\
\hline \multicolumn{5}{|l|}{ Sustainable development practices (SDPs) } \\
\hline Sustainable environmental practices & & 0.923 & 0.896 & 0.707 \\
\hline ECO1 & 0.863 & & & \\
\hline $\mathrm{ECO} 2$ & 0.844 & & & \\
\hline $\mathrm{ECO} 3$ & 0.844 & & & \\
\hline $\mathrm{ECO} 4$ & 0.891 & & & \\
\hline Sustainable social practices & & 0.914 & 0.878 & 0.727 \\
\hline SOC1 & 0.845 & & & \\
\hline SOC2 & 0.882 & & & \\
\hline SOC3 & 0.830 & & & \\
\hline SOC4 & 0.854 & & & \\
\hline Corporate green innovation (CGI) & & 0.929 & 0.909 & 0.686 \\
\hline CGI1 & 0.812 & & & \\
\hline CGI2 & 0.813 & & & \\
\hline CGI3 & 0.823 & & & \\
\hline CGI4 & 0.832 & & & \\
\hline CGI5 & 0.859 & & & \\
\hline CGI6 & 0.829 & & & \\
\hline
\end{tabular}


accumulated more than $33.9 \%$ of the variance; thus, the problem of common method variance is not found in this research because this value is below the cut-off value of $40 \%$ (Hair et al., 2017). Further, we also assessed full collinearity in SmartPLS, as suggested by Kock (2015). This is a modernised and more consistent method. All variance inflation factor (VIF) values are less than the threshold value of 3.3 , signifying that the model does not have any CMB issues (Kock, 2015).

To control for social desirability bias (SDB), the respondents were informed that their responses would be kept confidential and anonymous, thereby motivating them to complete the survey honestly. Second, the survey was self-administered as various studies report that a self-administered survey reduces the effect of SDB. Thus, honesty and a self-administered approach were used to minimise SDB in this study (Bhutto et al., 2020).

Nonresponse bias was examined by employing the time-trend extrapolation method. This is the most commonly applied method, including comparing the early and late quartiles of the responses by employing $t$ tests across all constructs that did not show any nonresponse bias in the data for this study.

\subsection{Analysis of measurement model}

The measurement or outer model is assessed following the guidelines of Hair et al. (2017). Results revealed that Cronbach's alpha and composite reliability values were greater than the 0.70 critical value level, as suggested by Cohen (1988). The average variance extracted (AVE) of all constructs was more than 0.50 , and the standardised factor loading value of all the constructs' items was also above 0.70 . Detailed findings of validity and reliability are presented in Table 2 . The VIF was also measured to assess multicollinearity for all the measurement items less than 3.3. Hair et al. (2017) suggested that the cut-off value of VIF must be less than 5.0 to avoid multicollinearity. Thus, there is no issue of multicollinearity.

Fornell and Larcker's criterion is employed to estimate the discriminant validity (DV). The AVE's square root value should be greater than the correlation values of the constructs that specify the DV (Fornell \& Larcker, 1981). Second, the heterotrait-monotrait (HTMT) ratio of correlations was estimated as suggested by Henseler et al. (2015) as the modernised approach for analysing DV. The results are presented in Tables 3 and 4. All values are less than a cut-off value of 0.85 , indicating no DV problem (Henseler et al., 2015).

\section{3 | Analysis of structural model}

The structural or inner model exhibits causal connections among underlying relationships (Hair et al., 2017). Mainly, it was evaluated through path coefficient $(\beta)$, explanatory power $\left(R^{2}\right)$ and predictive relevance $\left(Q^{2}\right) . R^{2}$ values of ENV were 0.293 , ECO was 0.220 , SOC was 0.166 and $C G I$ was 0.260 , supporting the model's predictive power (Hair et al., 2017). $Q^{2}$ values following blindfolding procedures of ENV were 0.280 , ECO was 0.203 , SOC was 0.137 and CGI was 0.251 . All $Q^{2}$ values are greater than zero. Hence, this model has good predictive relevance for endogenous constructs (Hair et al., 2017). Moreover, the value of SRMR ('standardised root mean square residual') is 0.0570 , which is below the threshold of 0.08 ; therefore, it confirms the overall fitness of the PLS path model (Hair et al., 2017). Following the formula $\mathrm{GoF}=\sqrt{\left(\mathrm{AVE} \times R^{2}\right)}$, we have also calculated the GoF value, which is 0.406 , showing a large model fit (Wetzels et al., 2009). For hypotheses testing, we employed the bootstrapping approach with 5000 resamples. All direct hypothesised paths were significant, except KACQ to SOC (H1c: $\beta=0.044)$ and KDISS to ECO ( $\mathrm{H} 3 \mathrm{~b}$ : $\beta=0.059$ ).

The indirect relationship of KMP towards CGI through a mediator is also accepted, showing results $(\beta=0.156)$ using an indirect effect mediation approach (Hair et al., 2017). For the assessment of the

TAB LE 4 Discriminant validity by HTMT ratio

\begin{tabular}{llllllll} 
& 1 & 2 & 3 & 4 & 5 & 6 & 7 \\
\hline ECO & & & & & & \\
ENV & 0.632 & & & & & \\
\hline CGI & 0.410 & 0.507 & & & & \\
KACQ & 0.465 & 0.431 & 0.397 & & & \\
\hline KAPP & 0.371 & 0.441 & 0.604 & 0.391 & & \\
\hline KDISS & 0.337 & 0.519 & 0.437 & 0.550 & 0.465 & \\
\hline SOC & 0.380 & 0.578 & 0.423 & 0.226 & 0.399 & 0.313 \\
\hline
\end{tabular}

TAB LE 3 Discriminant validity by Fornell-Larcker

\begin{tabular}{|c|c|c|c|c|c|c|c|}
\hline & 1 & 2 & 3 & 4 & 5 & 6 & 7 \\
\hline $\mathrm{ECO}$ & 0.861 & & & & & & \\
\hline ENV & 0.567 & 0.841 & & & & & \\
\hline CGI & 0.372 & 0.463 & 0.828 & & & & \\
\hline KACQ & 0.423 & 0.399 & 0.368 & 0.831 & & & \\
\hline KAPP & 0.336 & 0.407 & 0.555 & 0.366 & 0.844 & & \\
\hline KDISS & 0.302 & 0.465 & 0.393 & 0.500 & 0.420 & 0.810 & \\
\hline SOC & 0.351 & 0.533 & 0.397 & 0.228 & 0.376 & 0.298 & 0.853 \\
\hline
\end{tabular}

Note: Italic values are the square root of relevant AVE. 
degree of this indirect effect, we calculated the value of variance accounted for (VAF) by the formula (a1b1)/(a1b1 + $\left.c^{\prime}\right)$. By calculation, we obtained a value of $0.2804(28.04 \%>20 \%$ and $<80 \%)$, which shows partial mediation (Hair et al., 2017). We also calculated the significance level of all dimensions of KMP (KACQ, KDISS and KAPP) towards $\mathrm{CGI}$, which all are significant. All the control variables with $\beta$ values (gender $=-0.008$, age $=-0.034$, education $=0.002$, job experience $=-0.061$ and job title $=0.029)$ are insignificant. The overall results are shown in Table 5.

\section{4 | Robustness test: fsQCA}

Following prior social scientists Hernández-Perlines et al. (2016), Shahzad et al. (2019), Woodside (2017) and Zafar et al. (2021), this research also used fsQCA to identify the phenomenon and veracity of SEM results on an each case basis to understand the overall effects. The comparative assessment of SEM and fsQCA will unveil robustness and match in the observed data and study model. This method employs a fuzzy dataset to carry out standard comparisons and offers researchers a substitute quantitative tool (Ragin et al., 2017). Because this study used a Likert scale, data calibration is required to apply fsQCA. Twenty-five cases were selected randomly from the dataset for fsQCA analysis in this study. For calibration, we used fsQCA software and calibrated the values into a fuzzy triangular set representing [7, 5 and 3] (Ragin et al., 2017).

As specified in Table 6, the researcher must observe the necessity for each causal condition and its negation to test the hypotheses. The consistency values above 0.80 were considered 'always necessary', while less than 0.80 were considered 'usually necessary'. However,

TABLE 5 Hypotheses assessment

\begin{tabular}{|c|c|c|c|c|c|}
\hline & Hypothesised path & $\beta$ value & $t$ value & $p$ value & Decision \\
\hline $\mathrm{H} 1 \mathrm{a}$ & $\mathrm{KACQ} \rightarrow \mathrm{ENV}$ & 0.175 & 2.632 & 0.009 & Supported \\
\hline $\mathrm{H} 1 \mathrm{~b}$ & $\mathrm{KACQ} \rightarrow \mathrm{ECO}$ & 0.323 & 4.439 & 0.000 & Supported \\
\hline $\mathrm{H} 1 \mathrm{c}$ & $\mathrm{KACQ} \rightarrow \mathrm{SOC}$ & 0.044 & 0.692 & 0.489 & Unsupported \\
\hline $\mathrm{H} 2 \mathrm{a}$ & KDISS $\rightarrow$ ENV & 0.284 & 4.183 & 0.000 & Supported \\
\hline $\mathrm{H} 2 \mathrm{~b}$ & $\mathrm{KDISS} \rightarrow \mathrm{ECO}$ & 0.059 & 0.975 & 0.330 & Unsupported \\
\hline $\mathrm{H} 2 \mathrm{c}$ & $\mathrm{KDISS} \rightarrow \mathrm{SOC}$ & 0.152 & 2.311 & 0.021 & Supported \\
\hline H3a & $\mathrm{KAPP} \rightarrow \mathrm{ENV}$ & 0.223 & 3.830 & 0.000 & Supported \\
\hline $\mathrm{H} 3 \mathrm{~b}$ & $\mathrm{KAPP} \rightarrow \mathrm{ECO}$ & 0.193 & 3.616 & 0.000 & Supported \\
\hline $\mathrm{H} 3 \mathrm{c}$ & $\mathrm{KAPP} \rightarrow \mathrm{SOC}$ & 0.296 & 4.477 & 0.000 & Supported \\
\hline $\mathrm{H} 4 \mathrm{a}$ & $\mathrm{ENV} \rightarrow \mathrm{CGI}$ & 0.273 & 3.343 & 0.001 & Supported \\
\hline $\mathrm{H} 4 \mathrm{~b}$ & $\mathrm{ECO} \rightarrow \mathrm{CGI}$ & 0.146 & 2.162 & 0.031 & Supported \\
\hline $\mathrm{H} 4 \mathrm{c}$ & $\mathrm{SOC} \rightarrow \mathrm{CGI}$ & 0.200 & 3.047 & 0.002 & Supported \\
\hline H5 & $\mathrm{KMP} \rightarrow \mathrm{SDP} \rightarrow \mathrm{CGI}$ & 0.156 & 5.472 & 0.000 & Supported (partial mediation) \\
\hline \multicolumn{6}{|c|}{ Analysis of path coefficients (direct effects) } \\
\hline \multicolumn{2}{|c|}{$\mathrm{KACQ} \rightarrow \mathrm{CGI}$} & 0.104 & 2.906 & 0.004 & Supported \\
\hline \multicolumn{2}{|c|}{$\mathrm{KDISS} \rightarrow \mathrm{CGI}$} & 0.117 & 3.099 & 0.002 & Supported \\
\hline \multicolumn{2}{|c|}{$\mathrm{KAPP} \rightarrow \mathrm{CGI}$} & 0.149 & 4.462 & 0.000 & Supported \\
\hline
\end{tabular}

Note: $p$ values $=0.000$ shows significance level.

TAB LE 6 Analysis of necessary conditions for hypotheses

\begin{tabular}{|c|c|c|c|c|c|c|c|c|c|}
\hline \multicolumn{3}{|c|}{$\begin{array}{l}\text { Outcome variable: ENVfs } \\
(\mathrm{H} 1 \mathrm{a}, \mathrm{H} 2 \mathrm{a} \text { and } \mathrm{H} 3 \mathrm{a})\end{array}$} & \multicolumn{2}{|c|}{$\begin{array}{l}\text { Outcome variable: } \\
\text { ECOfs } \\
\text { (H1b, H2b and } \mathrm{H} 3 \mathrm{~b} \text { ) }\end{array}$} & \multicolumn{2}{|c|}{$\begin{array}{l}\text { Outcome variable: } \\
\text { SOCfs } \\
\text { (H1c, H2c and } H 3 c \text { ) }\end{array}$} & \multicolumn{3}{|c|}{$\begin{array}{l}\text { Outcome variable: CGIfs } \\
\text { (H4a, } \mathrm{H} 4 \mathrm{~b} \text { and } \mathrm{H} 4 \mathrm{c})\end{array}$} \\
\hline KACQfs & 0.7907 & 0.9473 & 0.8512 & 0.9221 & 0.7539 & 0.9429 & ENVfs & 0.9257 & 0.8064 \\
\hline$\sim$ KDISSfs & 0.4131 & 0.7654 & 0.4509 & 0.6972 & 0.4419 & 0.8547 & $\sim$ ECOfs & 0.5417 & 0.7384 \\
\hline KAPPfs & 0.8661 & 0.8864 & 0.9241 & 0.7895 & 0.8481 & 0.9062 & sOCfs & 0.8790 & 0.8134 \\
\hline KAPPfs & 0.3914 & 0.7375 & 0.4256 & 0.6693 & 0.4362 & 0.8580 & $\sim$ SOCfs & 0.4339 & 0.8583 \\
\hline
\end{tabular}


constructs that have a consistency value above 0.90 are considered 'almost always necessary'. Because a high consistency value is more significant than the coverage value in fsQCA, this condition may be included in all complex combinations of fsQCA analysis (HernándezPerlines et al., 2016; Ragin et al., 2017; Woodside, 2017). KAPPfs for ECOfs and ENVfs for CGIfs were the only conditions with consistency values above 0.90 and had a better chance to be part of all complex solutions and subset analyses for this research model.

To determine the sufficiency of this research model, we applied a truth table algorithm which is shown in Table 7. The best combination that leads towards CGIfs is KACQfs * KDISSfs * KAPPfs * ENVfs * ECOfs * SOCfs which has a higher value of consistency (0.8852), and the value of coverage (0.4678) with solution coverage and consistency values were 0.8363 and 0.8577 , respectively. The best combination must have the highest level of consistency and coverage (Ragin et al., 2017; Woodside, 2017). Furthermore, the findings of subset/superset analysis revealed that exogenous construct combinations had acceptable consistency and coverage values. The detailed results are given in Table 7. These findings show that all causative conditions are necessary for this research model. With a consistency value more than 0.74 and a coverage value ranging from 0.25 to 0.65 , the model is informative (Woodside, 2017). So the overall findings of PLS-SEM and fsQCA reveal a similar pattern of independent constructs towards $C G I$. Thus, the results of SEM and fsQCA are aligned and reliable.

\section{5 | Discussion of key findings}

This research integrated the RBV to develop the framework that analyses the multidimensional relationship among the KMP, SDPs and $\mathrm{CGI}$, which has previously been less researched. CGI is swiftly becoming an imperative tool for SD. Organisations are compelled continuously to improve their CGI by alleviating and addressing environmental concerns. On the other hand, CGI might be a challenging, knowledge-intensive undertaking with many complexities. Our results found that KACQ has a positive relationship towards the ENV and ECO, supporting $\mathrm{H} 1 \mathrm{a}$ and $\mathrm{H} 1 \mathrm{~b}$. However, it has an insignificant relationship with $\mathrm{SOC}(\beta=0.044)$, rejecting $\mathrm{H} 1 \mathrm{c}$ and supporting prior studies in a broader context (Awan et al., 2020; Song et al., 2020;
Zhang et al., 2020). This insignificant result demonstrates the need for developing an absorptive capacity that allows manufacturers to absorb knowledge from various stakeholders and act swiftly to overcome societal issues in emerging countries. KDISS has a positive relationship with ENV and $\mathrm{SCO}$, supporting $\mathrm{H} 2 \mathrm{a}$ and $\mathrm{H} 2 \mathrm{c}$. However, it has an insignificant relationship with ECO $(\beta=0.059)$, rejecting $\mathrm{H} 2 \mathrm{~b}$. Recent studies are also akin to our results (Lim et al., 2017; Song et al., 2020). However, some studies also oppose the findings of Darroch (2005), as introverted employees avoid communicating and sharing knowledge, which is the real cause behind less sharing of knowledge among employees, thus, affecting sustainable economic practices.

Further, KAPP has a positive relationship with all dimensions of SDP, supporting $\mathrm{H} 3 \mathrm{a}$ to $\mathrm{H} 3 \mathrm{c}$. To improve SDP, the firm needs to enforce previously acquired knowledge efficiently to enhance consumers' satisfaction (Nidumolu et al., 2013). This research study findings also reinforce earlier findings (Abbas \& Sağsan, 2019; Mills \& Smith, 2011; Shahzad, Qu, Zafar, Rehman, \& Islam, 2020). KAPP is a fundamental element that allows the organisation to generate sustainable products by implementing innovative technologies. In emerging economies such as Pakistan, SDPs and CGI are in their early phases. Besides, in developed countries, regulatory bodies support sustainable practices through penalties for generating heavy pollution and carbon tax, which motivate firms and create pressure on them not to be involved in polluting activities.

SDPs are considered to be critical drivers of green innovation, and these will contribute to environmental performance. This study shows that all SDP dimensions lead towards CGI, accepting all hypotheses of $\mathrm{H} 4$ and consistent with prior studies (Awan et al., 2020; Chang, 2016; Huang \& Li, 2017; Saunila et al., 2018). Awan et al. (2020) suggested that SDP would improve green innovation by integrating innovative and cleaner production technologies. Per our findings, ENV is considered to be the most influential driver for CGI $(\beta=0.273)$, followed by SOC $(\beta=0.200)$ and ECO $(\beta=0.146)$. Organisations should consider their operational effects on CGI by recognising the benefits of investment in environment management (IEM) and an environment management system (EMS) (Awan et al., 2020; Hojnik \& Ruzzier, 2016). Socially responsible organisations are more supportive in fulfilling the consumers' requirements without harming the environment as the demand for eco-friendly

TABLE 7 fsQCA results from complex situation

Truth table analysis

\begin{tabular}{|c|c|c|c|c|}
\hline \multirow{2}{*}{\multicolumn{2}{|c|}{ Outcome: CGIfs = f (KACQfs, KDISSfs, KAPPfs, ENVfs, ECOfs, SOCfs) }} & \multirow[b]{2}{*}{ Consistency } & \multicolumn{2}{|l|}{ Coverage } \\
\hline & & & Unique & Raw \\
\hline \multicolumn{2}{|c|}{ KACQfs * KDISSfs * KAPPfs * ENVfs * ECOfs * SOCfs } & 0.8852 & 0.3143 & 0.4678 \\
\hline Solution coverage & 0.8363 & & & \\
\hline Solution consistency & 0.8577 & & & \\
\hline \multicolumn{2}{|c|}{ Subset/superset analysis for research model } & Consistency & Coverage & Combined \\
\hline \multicolumn{2}{|c|}{ KACQfs * KDISSfs * KAPPfs * ENVSfs * ECOSfs * SOCSfs } & 0.9817 & 0.6732 & 0.8164 \\
\hline \multicolumn{2}{|c|}{ KACQfs * KAPTfs * ENVSfs * ECOSfs * SOCSfs } & 0.9826 & 0.7054 & 0.8357 \\
\hline
\end{tabular}


products has been growing (Tseng et al., 2018). Further, reducing production costs and minimising energy consumption are the most influential drivers and directly related to ECO, ultimately affecting CGI.

We suggested that CGI is achieved when SDPs have become a compulsory part of organisations' knowledge-driven strategies regarding our last hypothesis. The results revealed that SDP complementary partial mediates ( $\beta=0.156$ ), thus supporting $\mathrm{H} 5$. We also tested each dimension of the KMP towards CGI; all are significant and provided in Table 5. Lastly, the overall results of fsQCA endorse that all embedded constructs are necessary to affect the CGI. Thus, we should consider the significance of the KMP and SDP for achieving CGI outcomes.

\section{6 | CONCLUSION AND RESEARCH IMPLICATIONS}

\section{$6.1 \mid$ Conclusion}

This research contributes to the rising field of research on SD and green innovation by analysing the relationship between the KMP, SDP and CGI by adopting mixed methodology SEM and fsQCA. Our findings suggest that all dimensions of the KMP (acquisition, dissemination and application) significantly impact SDP dimensions (environment, economic and social). Further, all SDP dimensions significantly affect $\mathrm{CGI}$, which demonstrates the prominence of knowledge in this field. Additionally, the considerable mediating role of SDP has also illuminated another contribution of this study. The findings of fsQCA unveiled the robustness by highlighting the necessary conditions and truth table algorithm for all constructs towards CGI. The conclusion of these findings proposed that knowledge is a tool to achieve the organisational desired goal by encompassing SDP into operational processes. By providing the right knowledge to the ideal individual at the opportune time under the right circumstances, employees can choose to improve performance. The KMP is a fundamental tool for organisations' employees to cooperate and guarantee constant development in all organisational divisions to increase SD.

\section{2 | Theoretical and practical contribution}

The results of the current study offer the following theoretical contributions. First, this research proposed a conceptual model based on RBV, providing various novel correlations by addressing the scarcity in the previous literature in green innovation. This research is one of the early studies introducing that the KMP could help achieve and utilise knowledge resources effectively, smoothing operations and improving SDPs and CGI, particularly in manufacturing industries. Second, this study widens our understanding that all aspects of SDPs (such as environment, economic and social) are pivotal in improving the CGI. Due to greater sharing and application of knowledge among stakeholders, organisations alter the manufacturing process by adopting SDPs and can identify how and where the waste can be used to make a by-product or to reduce its harmful effect on the environment (An et al., 2021).

Third, this research also measured the mediating role of SDPs, which further propose viable solutions for both cost efficiency and environmental degradation, ultimately enhancing green performance. For example, the acceptance of electric and hybrid vehicles globally certifies that SDPs can transmute a massive carbon emission industry into a green, sustainable and cost-effective industry. Lastly, integrating the dual methodology (i.e., PLS-SEM and fsQCA) delivers novel insights and ensures the necessity of all exogenous constructs to contribute towards CGI individually.

The research has several practical contributions, which endorse the importance of an internal KMP as an underlying mechanism to realise the potential benefits of SDPs in their processes to become more eco-friendly. First, after recognising the significance of KMP, policymakers should be vigilant and launch specific training and development programmes for workforce development for evolving a sustainable organisation that follows the green growth agenda to generate more revenue and reduce their environmental impact. Second, this study encourages top management and professionals to integrate SDPs; however, successful implementation is contingent on acquiring, assimilating and applying knowledge to their operations. That will help develop a robust monetary penalty and rebate mechanism for manufacturing organisations that violate relevant environmental laws. Regulatory bodies should provide tax rebate and concessional loans to the concerned stakeholders to integrate sustainable practices into organisational operations.

Third, given the SDGs put forward by the United Nations, there is massive pressure from environmentalists and global leaders on emerging countries to improve SD by integrating innovative and cleaner production technologies. For Pakistan, there is an opportunity to learn from developed countries' practices and take corrective measures to prevent environmental degradation due to weak industrial actions. On the other hand, the government should encourage and work effectively to create a green business environment, such as the 'Punjab Green Development Program', and make it easier for organisations to reduce their reliance on fossil fuels and utilise renewable energy resources (World Bank, 2018). That will raise environmental awareness among businesses and improve green innovation.

\section{3 | Limitations and future research}

Because of limited resources and time, this study has some limitations, which may enable future research. For this study, we used a crosssectional approach; an experimental or longitudinal study is suggested for the future to obtain more decisive results. We primarily collected data from a developing country. In the future, researchers are recommended to replicate this model and extend this study to diverse regions to have a more thorough examination of circular economy initiatives; these initiatives have not been a priority for sustainable product design in global industries (Awan et al., 2020). A comparison study is also highly recommended, which may improve the 
generalisability of this study. Our research has documented that the KMP is essential for SDPs and CGI. Lastly, future researchers could also incorporate other moderating or mediating variables such as green knowledge-sharing behaviour, absorptive capabilities and internal and external knowledge transfer regarding sustainability objectives.

\section{ACKNOWLEDGEMENTS}

The authors would like to thank the reviewers and the editors for their valuable comments, which enabled us to improve the quality of the paper. We are also grateful to the National Natural Science Foundation of China (71974028) for funding our research.

\section{ORCID}

Mohsin Shahzad (DD https://orcid.org/0000-0002-2101-8619

Andrea Appolloni (iD) https://orcid.org/0000-0001-5741-398X

\section{REFERENCES}

Abbas, J. (2020). Impact of total quality management on corporate green performance through the mediating role of corporate social responsibility. Journal of Cleaner Production, 242, 118458. https://doi.org/10. 1016/j.jclepro.2019.118458

Abbas, J., \& Sağsan, M. (2019). Impact of knowledge management practices on green innovation and corporate sustainable development: A structural analysis. Journal of Cleaner Production, 229, 611-620. https://doi.org/10.1016/j.jclepro.2019.05.024

Abdul-Rashid, S. H., Sakundarini, N., Raja Ghazilla, R. A., \& Thurasamy, R. (2017). The impact of sustainable manufacturing practices on sustainability performance: Empirical evidence from Malaysia. International Journal of Operations \& Production Management, 37(2), 182-204. https://doi.org/10.1108/IJOPM-04-2015-0223

An, H., Razzaq, A., Haseeb, M., \& Mihardjo, L. W. W. (2021). The role of technology innovation and people's connectivity in testing environmental Kuznets curve and pollution heaven hypotheses across the Belt and Road host countries: New evidence from Method of Moments Quantile Regression. Environmental Science and Pollution Research, 28(6), 5254-5270. https://doi.org/10.1007/s11356-020-10775-3

Andersén, J. (2021). A relational natural-resource-based view on product innovation: The influence of green product innovation and green suppliers on differentiation advantage in small manufacturing firms. Technovation, 104, 102254. https://doi.org/10.1016/j.technovation.2021. 102254

Ardito, L., Petruzzelli, A. M., Pascucci, F., \& Peruffo, E. (2019). Inter-firm $R \& D$ collaborations and green innovation value: The role of family firms' involvement and the moderating effects of proximity dimensions. Business Strategy and the Environment, 28, 185-197. https://doi. org/10.1002/bse.2248

Awan, U., Arnold, M. G., \& Golgeci, I. (2020). Enhancing green product and process innovation: Towards an integrative framework of knowledge acquisition and environmental investment. Business Strategy and the Environment, 30, 1283-1295. https://doi.org/10.1002/bse.2684

Barney, J. (1991). Firm resources and sustained competitive advantage. Journal of Management, 17(1), 99-120. https://doi.org/10.1177/ 014920639101700108

Barney, J. B., Ketchen, D. J. Jr., \& Wright, M. (2011). The future of resource-based theory: Revitalisation or decline? Journal of Management, 37(5), 1299-1315. https://doi.org/10.1177/ 0149206310391805

Bhutto, T. A., Farooq, R., Talwar, S., Awan, U., \& Dhir, A. (2020). Green inclusive leadership and green creativity in the tourism and hospitality sector: Serial mediation of green psychological climate and work engagement. Journal of Sustainable Tourism, (February), 1-22. https:// doi.org/10.1080/09669582.2020.1867864

Chang, C.-H. (2016). The determinants of green product innovation performance. Corporate Social Responsibility and Environmental Management, 23(2), 65-76. https://doi.org/10.1002/csr.1361

Chen, Y. S., Lai, S. B., \& Wen, C. T. (2006). The influence of green innovation performance on corporate advantage in Taiwan. Journal of Business Ethics, 67(4), 331-339. https://doi.org/10.1007/s10551006-9025-5

Cohen, J. (1988). Statistical power analysis for the behavioral sciences (2nd ed.). Lawrence Erlbaum Associates. https://doi.org/10.1234/ 12345678

Cui, R., Wang, J., Xue, Y., \& Liang, H. (2020). Interorganizational learning, green knowledge integration capability and green innovation. European Journal of Innovation Management. https://doi.org/10.1108/ EJIM-11-2019-0325

Darroch, J. (2005). Knowledge management, innovation and firm performance. Journal of Knowledge Management, 9(3), 101-115. https://doi. org/10.1108/13673270510602809

Davenport, M., Delport, M., Blignaut, J. N., Hichert, T., \& van der Burgh, G. (2019). Combining theory and wisdom in pragmatic, scenario-based decision support for sustainable development. Journal of Environmental Planning and Management, 62(4), 692-716. https://doi.org/10.1080/ 09640568.2018 .1428185

Ding, X., Qu, Y., \& Shahza, M. (2019). The impact of environmental administrative penalties on the disclosure of environmental information. Sustainability, 11(20), 5820. https://doi.org/10.3390/ su11205820

Elkington, J. (1998). Partnerships from cannibals with forks: The triple bottom line of 21st-century business. Environmental Quality Management, 8(1), 37-51. https://doi.org/10.1002/tqem.3310080106

Fornell, C., \& Larcker, D. F. (1981). Evaluating structural equation models with unobservable variables and measurements error. Journal of Marketing Research, 18(4), 39-50. https://doi.org/10.1177/ 002224378101800104

Geng, D., Lai, K.-H., \& Zhu, Q. (2021). Eco-innovation and its role for performance improvement among Chinese small and medium-sized manufacturing enterprises. International Journal of Production Economics, 231(July 2020), 107869. https://doi.org/10.1016/j.ijpe.2020. 107869

Global Innovation Index. (2018). Key findings report. Retrieved from https://www.globalinnovationindex.org/about-gii\#keyfindings

Grant, R. M. (1997). The knowledge-based view of the firm: Implications for management practice. Long Range Planning, 30(3), 450-454. https://doi.org/10.1016/S0024-6301(97)00025-3

Gupta, H., \& Barua, M. K. (2018). A framework to overcome barriers to green innovation in SMEs using BWM and fuzzy TOPSIS. Science of the Total Environment, 633, 122-139. https://doi.org/10.1016/j. scitotenv.2018.03.173

Hair, J. F., Hult, G. T. M., Ringle, C. M., \& Sarstedt, M. (2017). A primer on partial least squares structural equation modeling (PLS-SEM) (2nd ed., Vol. 46, pp. 184-185). SAGE Publications.

Harman, H. H. (1976). Modern factor analysis (3rd ed.). University of Chicago Press.

Hart, O. (1995). Corporate governance: Some theory and implications. The Economic Journal, 105(430), 678-689. https://doi.org/10.2307/ 2235027

Henseler, J., Ringle, C. M., \& Sarstedt, M. (2015). A new criterion for assessing discriminant validity in variance-based structural equation modeling. Journal of the Academy of Marketing Science, 43(1), 115-135. https://doi.org/10.1007/s11747-014-0403-8

Hernández-Perlines, F., Moreno-García, J., \& Yañez-Araque, B. (2016). The mediating role of competitive strategy in international entrepreneurial orientation. Journal of Business Research, 69(11), 5383-5389. https:// doi.org/10.1016/j.jbusres.2016.04.142 
Hojnik, J., \& Ruzzier, M. (2016). What drives eco-innovation? A review of an emerging literature. Environmental Innovation and Societal Transitions, 19, 31-41. https://doi.org/10.1016/j.eist.2015.09.006

Huang, J. W., \& Li, Y. H. (2017). Green innovation and performance: The view of organizational capability and social reciprocity. Journal of Business Ethics, 145(2), 309-324. https://doi.org/10.1007/s10551-0152903-y

Jun, W., Ali, W., Bhutto, M. Y., Hussain, H., \& Khan, N. A. (2019). Examining the determinants of green innovation adoption in SMEs: $A$ PLS-SEM approach. European Journal of Innovation Management, 24, 67-87. https://doi.org/10.1108/EJIM-05-2019-0113

Khan, S. A. R., Razzaq, A., Yu, Z., \& Miller, S. (2021). Industry 4.0 and circular economy practices: A new era business strategies for environmental sustainability. Business Strategy and the Environment. https://doi. org/10.1002/bse.2853

Kock, N. (2015). Common method bias in PLS-SEM: A full collinearity assessment approach. International Journal of E-Collaboration, 11(4), 1-10. https://doi.org/10.4018/ijec.2015100101

Lee, V. H., Leong, L. Y., Hew, T. S., \& Ooi, K. B. (2013). Knowledge management: A key determinant in advancing technological innovation? Journal of Knowledge Management, 17(6), 848-872. https://doi.org/10. 1108/JKM-08-2013-0315

Li, D., Zheng, M., Cao, C., Chen, X., Ren, S., \& Huang, M. (2017). The impact of legitimacy pressure and corporate profitability on green innovation: Evidence from China top 100. Journal of Cleaner Production, 141, 41-49. https://doi.org/10.1016/j.jclepro.2016.08.123

Lim, M. K., Tseng, M.-L. L., Tan, K. H., \& Bui, T. D. (2017). Knowledge management in sustainable supply chain management: Improving performance through an interpretive structural modelling approach. Journal of Cleaner Production, 162, 806-816. https://doi.org/10.1016/j. jclepro.2017.06.056

Mills, A. M., \& Smith, T. A. (2011). Knowledge management and organisational performance: A decomposed view. Journal of Knowledge Management, 15(1), 156-171. https://doi.org/10.1108/ 13673271111108756

Nidumolu, R., Prahalad, C. K., \& Ranaswami, M. R. (2013). Why sustainability is now the key driver of innovation. IEEE Engineering Management Review, 41(2), 30-37. https://doi.org/10.1109/EMR.2013.6601104

Nonaka, I. (1994). A dynamic theory of organizational knowledge creation. Organization Science, 5(1), 14-37. https://doi.org/10.1287/orsc.5.1.14

Ooi, K. B. (2014). TQM: A facilitator to enhance knowledge management? A structural analysis. Expert Systems with Applications, 41(11), 5167-5179. https://doi.org/10.1016/j.eswa.2014.03.013

Podsakoff, P. M., MacKenzie, S. B., Lee, J. Y., \& Podsakoff, N. P. (2003). Common method biases in behavioral research: A critical review of the literature and recommended remedies. Journal of Applied Psychology, 88(5), 879-903. https://doi.org/10.1037/0021-9010.88.5.879

Prajapati, B., Dunne, M., \& Armstrong, R. (2010). Sample size estimation and power analysis. Optometry Today, 16, 123-132.

Ragin, C., Strand, S., \& Rubinson, C. (2017). User's guide to fuzzyset/qualitative comparative analysis. Charles Ragin and Sean Davey.

Razzaq, A., Sharif, A., Ahmad, P., \& Jermsittiparsert, K. (2021). Asymmetric role of tourism development and technology innovation on carbon dioxide emission reduction in the Chinese economy: Fresh insights from QARDL approach. Sustainable Development, 29(1), 176-193. https://doi.org/10.1002/sd.2139

Razzaq, A., Sharif, A., Najmi, A., Tseng, M.-L., \& Lim, M. K. (2021). Dynamic and causality interrelationships from municipal solid waste recycling to economic growth, carbon emissions and energy efficiency using a novel bootstrapping autoregressive distributed lag. Resources, Conservation and Recycling, 166, 105372. https://doi.org/10.1016/j. resconrec.2020.105372

Razzaq, A., Wang, Y., Chupradit, S., Suksatan, W., \& Shahzad, F. (2021). Asymmetric inter-linkages between green technology innovation and consumption-based carbon emissions in BRICS countries using quantile-on-quantile framework. Technology in Society, 66, 101656. https://doi.org/10.1016/j.techsoc.2021.101656

Sarkis, J., Gonzalez-Torre, P., \& Adenso-Diaz, B. (2010). Stakeholder pressure and the adoption of environmental practices: The mediating effect of training. Journal of Operations Management, 28(2), 163-176. https://doi.org/10.1016/j.jom.2009.10.001

Saunila, M., Ukko, J., \& Rantala, T. (2018). Sustainability as a driver of green innovation investment and exploitation. Journal of Cleaner Production, 179, 631-641. https://doi.org/10.1016/j.jclepro.2017. 11.211

Savino, M. M., \& Shafiq, M. (2018). An extensive study to assess the sustainability drivers of production performances using a resource-based view and contingency analysis. Journal of Cleaner Production, 204, 744-752. https://doi.org/10.1016/j.jclepro.2018.08.191

Shah, N., \& Soomro, B. A. (2021). Internal green integration and environmental performance: The predictive power of proactive environmental strategy, greening the supplier, and environmental collaboration with the supplier. Business Strategy and the Environment, 30(2), 1333-1344. https://doi.org/10.1002/bse.2687

Shahzad, M., Qu, Y., Zafar, A. U., Ding, X., \& Rehman, S. U. (2020). Translating stakeholders' pressure into environmental practices-The mediating role of knowledge management. Journal of Cleaner Production, 275, 124163. https://doi.org/10.1016/j.jclepro.2020.124163

Shahzad, M., Qu, Y., Zafar, A. U., Rehman, S. U., \& Islam, T. (2020). Exploring the influence of knowledge management process on corporate sustainable performance through green innovation. Journal of Knowledge Management, 24(9), 2079-2106. https://doi.org/10.1108/JKM11-2019-0624

Shahzad, M., Qu, Y., Javed, S., Zafar, A., \& Rehman, S. (2020). Relation of environment sustainability to CSR and green innovation: $A$ case of Pakistani manufacturing industry. Journal of Cleaner Production, 253, 119938. https://doi.org/10.1016/j.jclepro.2019.119938

Shahzad, M., Qu, Y., Rehman, S., Zafar, A., Ding, X., \& Abbas, J. (2019). Impact of knowledge absorptive capacity on corporate sustainability with mediating role of CSR: Analysis from the Asian context. Journal of Environmental Planning and Management, 63(2), 148-174.

Song, M., Yang, M. X., Zeng, K. J., \& Feng, W. (2020). Green knowledge sharing, stakeholder pressure, absorptive capacity, and green innovation: Evidence from Chinese manufacturing firms. Business Strategy and the Environment, 29(3), 1517-1531. https://doi.org/10.1002/bse. 2450

Song, W., \& Yu, H. (2018). Green innovation strategy and green innovation: The roles of green creativity and green organizational identity. Corporate Social Responsibility and Environmental Management, 25(2), 135-150. https://doi.org/10.1002/csr.1445

Tseng, M.-L., Lim, M. K., \& Wu, K.-J. (2018). Corporate sustainability performance improvement using an interrelationship hierarchical model approach. Business Strategy and the Environment, 27, 1334-1346. https://doi.org/10.1002/bse.2182

United Nations. (2018). Transforming our World: The 2030 Agenda for Sustainable Development. Stockholm: United Nations.

Wang, C. H. (2020). An environmental perspective extends market orientation: Green innovation sustainability. Business Strategy and the Environment, 29, 1-12. https://doi.org/10.1002/bse.2561

Wetzels, M., Odekerken-Schröder, G., \& van Oppen, C. (2009). Using PLS path modeling for assessing hierarchical construct models: Guidelines and empirical illustration. MIS Quarterly, 33(1), 177-196. https://doi. org/10.2307/20650284

Woodside, A. G. (2017). Moving beyond multiple regression analysis and symmetric tests to algorithms and asymmetric tests. In Bad to good (pp. 83-111). Emerald Group Publishing Limited.

World Bank. (2018). World Bank Project: Punjab Green Development Program. Retrieved March 2, 2021, from https://projects.worldbank.org/ en/projects-operations/project-detail/P165388?lang\%2525C2\% 2525BCen $=$ 
Yousaf, Z. (2021). Go for green: Green innovation through green dynamic capabilities: Accessing the mediating role of green practices and green value. Environmental Science and Pollution Research. https://doi.org/10. 1007/s11356-021-14343-1

Zafar, A. U., Qiu, J., Li, Y., Wang, J., \& Shahzad, M. (2021). The impact of social media celebrities' posts and contextual interactions on impulse buying in social commerce. Computers in Human Behavior, 115(October 2019), 106178. https://doi.org/10.1016/j.chb.2019.106178

Zhang, Y., Sun, J., Yang, Z., \& Wang, Y. (2020). Critical success factors of green innovation: Technology, organisation and environment readiness. Journal of Cleaner Production, 264, 121701. https://doi.org/10. 1016/j.jclepro.2020.121701
How to cite this article: Shahzad, M., Qu, Y., Zafar, A. U., \& Appolloni, A. (2021). Does the interaction between the knowledge management process and sustainable development practices boost corporate green innovation? Business Strategy and the Environment, 1-17. https://doi.org/10.1002/bse.2865

\section{APPENDIX A}

\section{SUMMARY OF LITERATURE REVIEW}

\begin{tabular}{|c|c|c|c|}
\hline Authors & Methods and theory & Objectives & Integrated constructs \\
\hline Yousaf (2021) & $\begin{array}{l}457 \text { surveys theory of planned } \\
\text { behaviour }\end{array}$ & $\begin{array}{l}\text { How green dynamic capabilities and } \\
\text { green practices affect green } \\
\text { innovation in SMEs }\end{array}$ & $\begin{array}{l}\text { Green dynamic capabilities, green } \\
\text { practices, green value cocreation } \\
\text { and green innovation }\end{array}$ \\
\hline Geng et al. (2021) & 382 surveys contingency theory & $\begin{array}{l}\text { How eco-innovation efforts can } \\
\text { bring performance improvements } \\
\text { by integrating eco-innovation and } \\
\text { traditional environmental } \\
\text { management (TEM) practices }\end{array}$ & $\begin{array}{l}\text { Eco-innovation, internal source } \\
\text { reduction, external compliance } \\
\text { and communication, internal } \\
\text { management and control and } \\
\text { environmental and economic } \\
\text { performance }\end{array}$ \\
\hline Zhang et al. (2020) & $\begin{array}{l}340 \text { surveys technology } \\
\text { organisation environment } \\
\text { framework }\end{array}$ & $\begin{array}{l}\text { To identify critical success factors of } \\
\text { green innovation: technology, } \\
\text { organisation and environment } \\
\text { readiness }\end{array}$ & $\begin{array}{l}\text { Technology, organisation, and } \\
\text { environment readiness, green } \\
\text { innovation, environmental } \\
\text { performance and firm } \\
\text { performance }\end{array}$ \\
\hline Awan et al. (2020) & 239 surveys conceptual model & $\begin{array}{l}\text { To explore knowledge acquisition } \\
\text { capability and investment in } \\
\text { environmental management to } \\
\text { mediate the impact of buyer- } \\
\text { driven knowledge transfer } \\
\text { activities on green product } \\
\text { innovation and green process } \\
\text { innovation }\end{array}$ & $\begin{array}{l}\text { Knowledge acquisition capability, } \\
\text { investment in environmental } \\
\text { management, knowledge transfer } \\
\text { activities, green product } \\
\text { innovation and green process } \\
\text { innovation }\end{array}$ \\
\hline Song et al. (2020) & $\begin{array}{l}247 \text { surveys organisational learning } \\
\text { theory }\end{array}$ & $\begin{array}{l}\text { How green knowledge sharing } \\
\text { affects absorptive capacity for } \\
\text { enhancing green innovation }\end{array}$ & $\begin{array}{l}\text { Stakeholders' pressure, buyer and } \\
\text { supplier green knowledge sharing, } \\
\text { green absorptive capacity and } \\
\text { green innovation }\end{array}$ \\
\hline $\begin{array}{l}\text { Shahzad, Qu, Zafar, Ding, and } \\
\text { Rehman (2020) }\end{array}$ & 318 surveys stakeholder theory & $\begin{array}{l}\text { How different stakeholders' } \\
\text { pressure (SP) influences CSR and } \\
\text { green innovation directly and by } \\
\text { the mediation of the knowledge } \\
\text { management process (KMP) }\end{array}$ & $\begin{array}{l}\text { Stakeholders' pressure, CSR, green } \\
\text { innovation and knowledge } \\
\text { management process }\end{array}$ \\
\hline
\end{tabular}




\begin{tabular}{|c|c|c|c|}
\hline Authors & Methods and theory & Objectives & Integrated constructs \\
\hline $\begin{array}{l}\text { Shahzad, Qu, Zafar, Rehman, } \\
\text { and Islam (2020) }\end{array}$ & $\begin{array}{l}475 \text { surveys resource-based view } \\
\text { theory }\end{array}$ & $\begin{array}{l}\text { To examine the role of the } \\
\text { knowledge management process } \\
\text { for corporate sustainable } \\
\text { performance with the integration } \\
\text { of green innovation and } \\
\text { organisational agility }\end{array}$ & $\begin{array}{l}\text { Acquisition, dissemination and } \\
\text { application of knowledge, green } \\
\text { innovation, organisational agility } \\
\text { and environment, economic and } \\
\text { social sustainability }\end{array}$ \\
\hline $\begin{array}{l}\text { Shahzad, Qu, Javed, Zafar, } \\
\text { and Rehman (2020) }\end{array}$ & $\begin{array}{l}282 \text { surveys theory of sustainable } \\
\text { development }\end{array}$ & $\begin{array}{l}\text { It aims to explore how different CSR } \\
\text { dimensions impact on } \\
\text { environmentally sustainable } \\
\text { development and further on } \\
\text { green innovation }\end{array}$ & $\begin{array}{l}\text { CSR practices, environmental } \\
\text { sustainability and green } \\
\text { innovation }\end{array}$ \\
\hline Abbas (2020) & $\begin{array}{l}331 \text { surveys theory of sustainable } \\
\text { development }\end{array}$ & $\begin{array}{l}\text { To identify how different } \\
\text { dimensions of total quality } \\
\text { management enhance corporate } \\
\text { green performance }\end{array}$ & $\begin{array}{l}\text { Leadership, strategic planning, } \\
\text { customer focus, process and } \\
\text { human resource management, } \\
\text { information analysis and CSR }\end{array}$ \\
\hline Song and Yu (2018) & $\begin{array}{l}135 \text { surveys organisational identity } \\
\text { and organisational creativity } \\
\text { theory }\end{array}$ & $\begin{array}{l}\text { How green innovation strategy, } \\
\text { creativity and organisational } \\
\text { identity influence green } \\
\text { innovation }\end{array}$ & $\begin{array}{c}\text { Green innovation strategy, green } \\
\text { creativity, green organisational } \\
\text { identity and green innovation }\end{array}$ \\
\hline Tseng et al. (2018) & $\begin{array}{l}50 \text { interviews resource-based view } \\
\text { theory }\end{array}$ & $\begin{array}{l}\text { To improve sustainability } \\
\text { performance through an } \\
\text { interrelationship hierarchical } \\
\text { model }\end{array}$ & $\begin{array}{l}\text { Environmental and economic } \\
\text { activities, customer and various } \\
\text { shareholders' management and } \\
\text { strategic operational controls }\end{array}$ \\
\hline Saunila et al. (2018) & 139 surveys conceptual model & $\begin{array}{l}\text { To identify the drivers for green } \\
\text { innovation regarding } \\
\text { sustainability }\end{array}$ & $\begin{array}{l}\text { Sustainability drivers, green } \\
\text { innovation investment and green } \\
\text { innovation exploitation }\end{array}$ \\
\hline Abdul-Rashid et al. (2017) & 443 surveys conceptual model & $\begin{array}{l}\text { To evaluate the impact of } \\
\text { sustainable practices on } \\
\text { sustainable performance }\end{array}$ & $\begin{array}{l}\text { Sustainable product design and } \\
\text { development, sustainable } \\
\text { manufacturing process, } \\
\text { sustainable supply chain } \\
\text { management and sustainable } \\
\text { end-of-life management }\end{array}$ \\
\hline Mills and Smith (2011) & $\begin{array}{l}189 \text { surveys resource-based view } \\
\text { theory }\end{array}$ & $\begin{array}{l}\text { To evaluate the impact of specific } \\
\text { knowledge management } \\
\text { resources (i.e., knowledge } \\
\text { management enablers and } \\
\text { processes) on organisational } \\
\text { performance }\end{array}$ & $\begin{array}{l}\text { Knowledge infrastructure } \\
\text { capabilities, knowledge process } \\
\text { capabilities and organisational } \\
\text { performance }\end{array}$ \\
\hline Sarkis et al. (2010) & $\begin{array}{l}157 \text { interviews stakeholder theory, } \\
\text { resource-based view theory }\end{array}$ & $\begin{array}{l}\text { To explore the role of stakeholder } \\
\text { pressure and employees' training } \\
\text { in the adoption of environmental } \\
\text { practices }\end{array}$ & $\begin{array}{l}\text { Environmental practices including } \\
\text { eco-design, source reduction, } \\
\text { environment management } \\
\text { systems, stakeholders' pressures } \\
\text { and training }\end{array}$ \\
\hline Darroch (2005) & 443 surveys conceptual model & $\begin{array}{l}\text { To provide significant empirical } \\
\text { evidence to support the role of } \\
\text { knowledge management in firm } \\
\text { performance }\end{array}$ & $\begin{array}{l}\text { Knowledge management process, } \\
\text { innovation and performance }\end{array}$ \\
\hline
\end{tabular}

